Удк 658:65.012.34(477)(08)

JEL classification: E62, F01, F02, 000

\section{Наталя ПРОКОПЕНКО}

здобувач,

Причорноморський науково-дослідний інститут економіки та інновацій, Україна E-mail: management@nuos.edu.ua ORCID: https://orcid.org/ 0000-0001-8919-2114

(C) Наталя Прокопенко, 2020

Отримано: 05.02.2020 p.

Прорецензовано: 16.02 .2020 р.

Рекомендовано до друку: 26.02.2020 р.

Опубліковано: 28.02.2020 p.

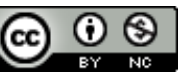

Ця стаття розповсюджується на умовах ліцензії Creative Commons AttributionNonCommercial 4.0, яка дозволяє необмежене повторне використання, розповсюдження та відтворення на будь-якому носії, за умови правильного цитування оригінальної роботи.
Наталя Прокопенко (Україна)

\section{ДРАЙВЕРИ ЕКОНОМІЧНИХ ТРАНСФОРМАЦІЙ У ЗАБЕЗПЕЧЕННІ ФУНКЦІОНАЛЬНОСТІ ДИЗАЙНУ СТРАТЕГІЧНОГО РОЗВИТКУ НАЦІОНАЛЬНОÏ ЕКОНОМІКИ}

\section{АНОТАЦІя}

Вступ. Основними учасниками трансформаційних процесів національної економіки виступають представники влади, громади та бізнесу. Зі сторони бізнесу виступають виробники та надавачі економічних продуктів та послуг, а зі сторони громади - споживачі економічних благ та послуг. Влада виражає свою співучасть у формуванні механізмів трансформаційних процесів національної економіки у вигляді нормативно-законодавчого та соціально-регулюючого впливу на формування економічних явищ i процесів.

Метою статті $€$ обрунтування драйверів економічних трансформацій у забезпеченні функціональності дизайну стратегічного розвитку національної економіки..

Методи (методологія). У досліджені застосовані загальнонаукові методи, зокрема теоретичного узагальнення - для узагальнення драйверів економічних трансформацій у забезпеченні функціональності дизайну; системного економічного аналізу - для обґрунтування моделі впливу економічних драйверів на трансформаційні процеси в контексті дизайнменеджменту.

Результати. За результатами проведених досліджень виокремлено види економічної діяльності та економічні процеси, що виступають основними драйверами розвитку національної економіки, які запропоновано поділяти на дві групи у залежності від стратегічних завдань, а саме: драйвери економічного зростання та драйвери економічних трансформацій. Драйверами економічного зростання виступають галузі та види економічної діяльності, ріст яких стимулює економічне зростання в інших секторах економіки та прямо впливає на відповідне зростання ВВП. На поточному етапі розвитку основними драйверами зростання національної економіки $€$ : розвиток транспортно-логістичної інфраструктури, сектору інформації та комунікацій та АПК.

Прокопенко Н. Драйвери економічних трансформацій у забезпеченні функціональності дизайну стратегічного розвитку національної економіки. Економічний аналіз. 2020. Том 30. № 1. Частина 2. С. 125-131.

DOI: https://doi.org/10.35774/econa2020.01.02.125

Ключові слова: національна економіка; дизайн менеджмент; трансформаційні процеси; драйвер економічних процесів; стратегічний розвиток. 
UDC 658:65.012.34(477)(08)

JEL classification: E62; F01; F02; 000

\section{Natalia PROKOPENKO}

PhD student,

Black Sea Research Institute of Economics and Innovation, Ukraine

E-mail: management@nuos.edu.ua

ORCID: https://orcid.org/ 0000-0001-8919-2114

(C) Natalia Prokopenko, 2020

\section{Received: 05.02.2020}

Revised: 16.02 .2020

Accepted: 26.02.2020

Online publication date: 28.02 .2020

\section{(i) (8)}

This is an Open Access article, distributed under the terms of the Creative Commons AttributionNonCommercial 4.0 license, which permits unrestricted re-use, distribution, and reproduction in any medium, provided the original work is properly cited.
Natalia Prokopenko (Ukraine)

\section{DRIVERS OF ECONOMIC TRANSFORMATIONS IN PROVIDING FUNCTIONALITY OF STRATEGIC DEVELOPMENT DESIGN OF NATIONAL ECONOMY}

\begin{abstract}
Introduction. The main participants in the transformation processes of the national economy are representatives of government, community and business. Producers and providers of economic products and services act on the business side, and consumers of economic goods and services act on the community side. The government expresses its complicity in the formation of mechanisms of transformational processes of the national economy in the form of normativelegislative and social-regulatory influence on the formation of economic phenomena and processes.

The purpose of the article is to substantiate the drivers of economic transformations in ensuring the design functionality of the strategic development of the national economy ..

Methods (methodology). The general scientific methods, in particular theoretical generalization - for generalization of drivers of economic transformations in maintenance of functionality of design are applied in research; system economic analysis - to substantiate the model of influence of economic drivers on transformation processes in the context of design management.

Results. According to the results of the research, the types of economic activity and economic processes that are the main drivers of national economy development are identified, which are proposed to be divided into two groups depending on strategic objectives, namely: drivers of economic growth and drivers of economic transformations. Drivers of economic growth are industries and types of economic activity, the growth of which stimulates economic growth in other sectors of the economy and directly affects the corresponding GDP growth. At the current stage of development, the main drivers of growth of the national economy are: the development of transport and logistics infrastructure, the information and communications sector and agriculture.
\end{abstract}

Prokopenko, N. (2020). Drivers of economic transformations in providing functionality of strategic development design of national economy. Economic analysis, 30 (1, Part 2), 125-131.

DOI: https://doi.org/10.35774/ econa2020.01.02.125

Keywords: national economy; design management; transformation processes; driver of economic processes; strategic development. 
www.econa.org.ua

\section{Вступ}

Функціональність дизайну складних систем, до яких належить національна економіка серед іншого визначається наявністю ефективних вертикальних та горизонтальних зв'язків, що дозволяють вловлювати імпульси від зовнішнього середовища та активно поширювати їх у системі, стимулюючи їі розвиток та самоорганізацію. Пошук драйверів економічного розвитку національної економіки у контексті дизайн - менеджменту зумовлений потребою забезпечення адаптивності та функціональної придатності проектованої моделі національної економіки у змінному середовищі. Драйвери в такій системі виконують роль комутантів між окремими елементами а також прискорювачами трансформаційних змін.

Актуальність вибудовування драйверів для забезпечення позитивних соціально-економічних трансформацій в Україні зумовила активізацію наукових досліджень у цьому напрямку. Як результат, у науковій літературі представлено різні позиції щодо визначення економічних драйверів та їх впливу на соціально-економічні трансформації.

у розвиток стратегічного управління національної економіки на засадах дизайн менеджменту, зробили значний внесок такі відомі українські вчені, як О.Терлецький, М. Павлик, М. Драгоманов, М. Зібер, С. Подолинський, М. Туган-Барановський, І. Вернадський, М. Вольський, І.ІІртищева, Г. Цехановецький, К. Воблій, Т. Войнаровський, І. Коропецький, Л. Чернюк, В. Копитко, І. Крамаренко та ін.

\section{Мета дослідження}

Метою статті $\epsilon$ обрунтування драйверів економічних трансформацій у забезпеченні функціональності дизайну стратегічного розвитку національної економіки.

\section{Виклад основного матеріалу}

На думку Кононової І. В., головна мета драйверів полягає у забезпеченні позитивних змін параметрів функціонування соціально-економічної системи як реакції на вплив зовнішніх і внутрішніх імпульсів. Драйвери не забезпечують повною мірою розвитку всієї соціально-економічної системи, проте формують для цього передумови шляхом проникнення різні підсистеми та сприяють розвитку мультиплікативного ефекту. Автор виділяє специфічні принципи, яким повинні відповідати визначені драйвери:

- «принцип постійної готовності до реагування на ймовірність нестійкого розвитку системи: визначає необхідність постійної готовності до можливого порушення рівноваги системи на будь-якому етапі її функціонування;

- принцип превентивної дій: краще запобігати загрозам нестійкого становища, ніж здійснювати нейтралізацію його негативних наслідків;

- принцип ефективності управлінських рішень: вибір того чи іншого управлінського рішення щодо вектора розвитку здійснюється в бік того, якому відповідає максимально можливе співвідношення результатів та витрат» [1, с. 121].

у традиційній моделі економічного розвитку, що сформована в Україні під драйверами економічного зростання розуміють насамперед галузі та сектори економіки розвиток яких забезпечує приріст ВВП а також внутрішні і зовнішні чинники, що впливають на збільшення обсягів виробництва продукції чи послуг (попит, конкуренція, зміни на глобальних ринках, інвестиції тощо). Зокрема, за даними міністерства розвитку економіки, торгівлі та сільського господарства України, «за результатами 2019 року економічна активність зберігалась на достатньо високому рівні - темпи зростання ВВП оцінено у 3,3\%, що майже співпадає з показником 2018 року. Водночас, змінились драйвери цього зростання. Так, суттєво уповільнилось зростання зведеного індексу виробництва товарів та послуг за основними видами економічної діяльності (3ІВ) - до 1,6\% загалом за 2019 рік, а в останні місяці року навіть спостерігалось його падіння. Насамперед, це відбувалося за рахунок виробничої сфери. Також незважаючи на черговий рекорд урожаю зернових, уповільнилось сільське господарство. Натомість високий внутрішній попит генерував високі показники в будівництві, торгівлі та низці галузей сфері послуг» [2].

Інновації як основний драйвер економічного розвитку та модернізації економіки розглядається у працях Крауса Н. М. [3], Писаренко Т. В., Кваші Т. К., Карлюка Г. В., Ляха Л. В. [4] та багатьох інших вітчизняних науковців. Нажаль, в умовах обмеженості ресурсів, передусім фінансових інноваційна діяльність в Україні фінансується на 9596\% за рахунок власних коштів підприємств. Основні види інновацій спрямовані на покращення та часткової модернізації матеріальнотехнологічної бази а також впровадження інноваційних видів продукції, що є новою лише для підприємств. В таких умовах, потенціал інноваційної діяльності як драйвера розвитку національної економіки використовується недостатньо. Однією з причин такого становища $€$ відсутність тісних взаємозв'язків між наукою, інноваційною діяльністю, капітальними інвестиціями та ВВП. На рис. 1 наведено динаміку приросту капітальних інвестицій, інноваційних витрат підприємств, витрат на НДДКР та ВВП.

Важливим драйвером економічного зростання у країнах ЄC та багатьох інших розвинених країнах виступає розвиток малого бізнесу. Це пов'язано із тим, що малі підприємства найбільш ефективно 
www.econa.org.ua

адаптуються до змінних умов середовища, займаючи ніші що не цікаві для великих підприємств, сприяють швидкій дифузії інновацій в усі сфери ринку. Як зауважують науковці Чорток Ю. В., Пімоненко Т. В. та Ус Я. О., розвиток малого бізнесу в Європі користується значною підтримкою влади, зокрема «у рамках Євросоюзу здійснюється політика підтримки малого підприємництва, що реалізує інноваційні бізнес-ідеї відповідно до результатів Четвертої промислової революції. У цьому напрямку основна мета євро політики полягає у збалансуванні сучасних умов функціонування ринку, інтересів держави і бізнесу. При цьому забезпечується підтримка оптимальних умов для підприємницької діяльності, збільшення конкурентоспроможності малого бізнесу» [5, c. 140].

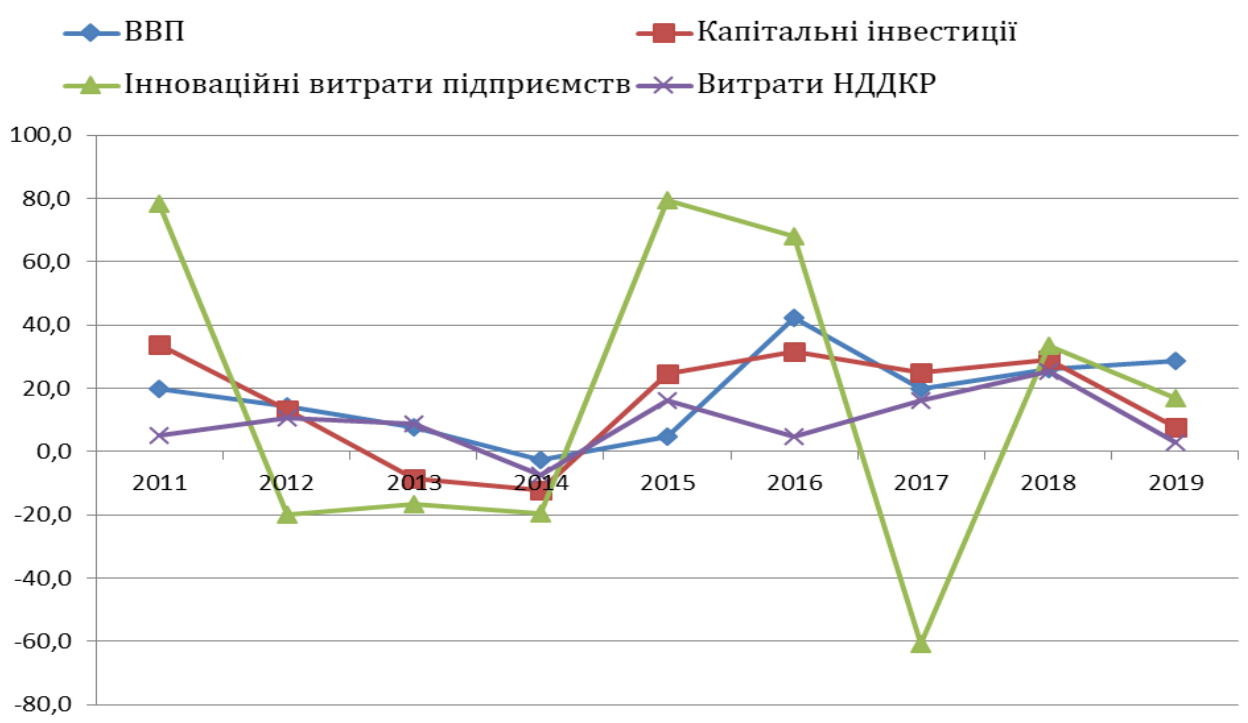

Рис. 1. Порівняльні темпи приросту ВВП, капітальних інвестицій, інноваційних витрат підприємств та витрат на НДДК в національній економіці, \% до попереднього періоду

Джерело: Срормовано автором за даними державної служби статистики України [6].

Зважаючи на досвід розвинених країн, малі підприємства можуть стати потужним драйвером економічного розвитку та трансформацій. Передумовами для цього має бути розроблені дієві, прозорі та інклюзивні програми розвитку малого бізнесу, що спрямовані не тільки для зростання кількості малих підприємств, а й створення умов для впровадження ними інноваційних технологій та виходу з тіньового сектору економіки.

Для покращення діяльності малих та середніх підприємств на рівні держави Попський А., пропонує здійснити низку заходів, спрямованих на підвищення ефективності функціонування господарюючих суб'єктів, а саме:

- «забезпечити функціонування такої організаційно-інституційної системи, яка б оперативно, адекватно та професійно реагувала на будь-які зміни в економіці та у правовій сфері;

- гармонізувати правове поле сфери малого та середнього підприємництва із внесенням відповідних змін до законодавства стосовно особливостей такого виду підприємництва 3 акцентуванням уваги на зростанні прозорості діяльності господарюючих суб'єктів;
- покращити інформаційне, а також фінансове і матеріально-технічне забезпечення господарюючих суб'єктів сфери малого та середнього підприємництва» [7, с. 265].

Проведені дослідження дозволили зробити висновок, що на рівні національної економіки драйвери, можна розділити на 2 групи, а саме: драйвери економічного зростання та драйвери економічних трансформацій.

Під драйверами економічного зростання ми розуміємо галузі та види економічної діяльності, ріст яких стимулює економічне зростання в інших секторах економіки та опосередковано впливає на відповідне зростання ВВП. При цьому, таке зростання може відбуватися як на основі інтенсивних (викликати якісні та структурні зміни в інших галузях з подальшим переростанням їх у кількісні показники), так і екстенсивних факторів (розширення ринків, збільшення обсягів виробництва, проникнення на нові ринки, що стимулюватиме відповідне збільшення обсягів виробництва чи послуг в інших сферах економіки). 

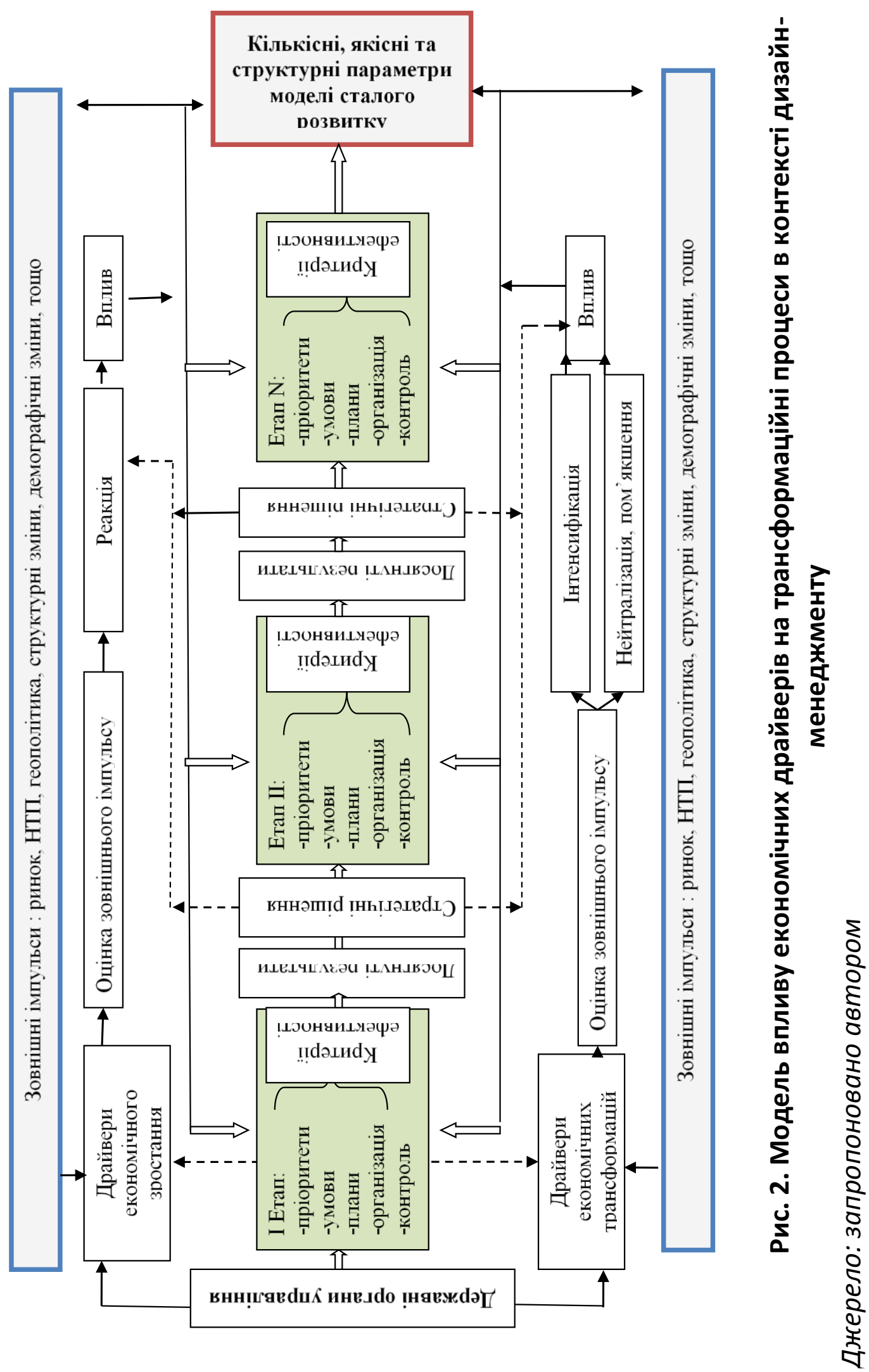
Особливістю трансформаційних драйверів $€$ їх гнучкість, тобто здатність створювати цілеспрямовані імпульси для розвитку економіки, забезпечуючи тим самим їі адаптивність до зовнішніх імпульсів як позитивних, так і негативних й тим самим підвищувати рівень керованості перетворень. Зміни параметрів трансформаційних драйверів, як реакція на зовнішні зміни виступає більш мобільним і гнучким інструментом економічної політики порівняно з драйверами зростання, а рішення пов'язані зі зміною вказаних параметрів мають набагато ширший та швидкий вплив на розвиток всіх складових соціально-економічної системи.

Доцільно підкреслити, що поділ драйверів на трансформаційні та стимулюючі $€$ умовним, оскільки їх вплив може створювати подвійний ефект, тобто водночас сприяти зростанню та якісним перетворенням за умови створення ефективних спрямовуючих взаємозв'язків між галузями i процесами в національній економіці. Схематично, роль економічних драйверів в процесах економічних трансформацій у контексті дизайн-менеджменту проілюстровано на рис. 2.

У контексті дизайн-менеджменту стратегічне управління економічними трансформаціями являється процесом, який складається 3 певних етапів економічних трансформацій, результатом реалізації якого $€$ система критеріальних соціальних, економічних та екологічних показників розвитку соціально-економічної системи, визначених в кількісних, якісних та структурних показниках. Для досягнення вказаних показників у процесі планування можуть залучатися драйвери економічного зростання та економічних трансформацій, із врахуванням таких їх параметрів, що здатні впливати на ефективність поставлених завдань.

Отже, з позиції дизайн-менеджменту, важливим завданням $€$ створення економічних, правових та інституційних умов для ефективного використання вказаних драйверів в державних інтересах, тобто забезпечення ними їх основних функцій, а саме: сприяти створенню та поширенню позитивних імпульсів для трансформаційного розвитку економіки в заданому векторі та нейтралізації чи пом'якшенню зовнішніх негативних імпульсів, плив яких створює бар'єри для ефективного функціонування соціально-економічних систем.

\section{Висновки та перспективи подальших розвідок}

Обгрунтовано, що ефективність, гнучкість та функціональність дизайну стратегічних перетворень у змінному середовищі залежить від наявності та ефективного застосування економічних драйверів, що дозволяють вловлювати імпульси від зовнішнього середовища та активно поширювати їх у системі, стимулюючи ії розвиток та самоорганізацію. Пошук драйверів економічного розвитку національної економіки у контексті дизайн - менеджменту зумовлений потребою забезпечення адаптивності та функціональної придатності проектованої моделі національної економіки у змінному середовищі. Драйвери в такій системі виконують роль комутантів між окремими елементами а також прискорювачами трансформаційних змін.

За результатами проведених досліджень виокремлено види економічної діяльності та економічні процеси, що виступають основними драйверами розвитку національної економіки, які запропоновано поділяти на дві групи у залежності від стратегічних завдань, а саме: драйвери економічного зростання та драйвери економічних трансформацій. Драйверами економічного зростання виступають галузі та види економічної діяльності, ріст яких стимулює економічне зростання в інших секторах економіки та прямо впливає на відповідне зростання ВВП. Драйверами економічних трансформацій, у свою чергу, виступають процеси, здійснення яких виступає водночас імпульсом та інструментом структурних і якісних перетворень у соціально-економічних системах на всіх стадіях трансформаційного процесу. Особливістю трансформаційних драйверів $\epsilon$ їх гнучкість, тобто здатність створювати цілеспрямовані імпульси для розвитку економіки, забезпечуючи тим самим їі адаптивність до зовнішніх імпульсів як позитивних, так і негативних й тим самим підвищувати рівень керованості перетворень. До таких драйверів віднесено: науково-технічну та інноваційну діяльність, інвестиційну діяльність, діяльність з впровадження цифрових технологій, розвиток малого бізнесу.

\section{СПИСОК ВИКОРИСТАНИХ ДЖЕРЕЛ}

1. Кононова І. В. Концептуальні основи формування драйверів розвитку соціально-економічних систем. Інтелект XXI -2016. № 6. C. $115-123$.

2. Міністерство розвитку економіки, торгівлі та сільського господарства України. https://www.me.gov.ua.
3. Краус Н. М. Інноваційна економіка в глобалізованому світі: інституціональний базис формування та траєкторія розвитку: монографія. Київ: Аграр Медіа Груп, 2019. 492 с.
4. Писаренко Т. В., Кваша Т. К., Карлюк Г. В., Лях Г. В. Інноваційна діяльність та ії вплив на економічний розвиток в Україні: монографія. Київ: УкрНТІ, 2015. 116 c. 
www.econa.org.ua

5. Чорток Ю. В., Пімоненко Т. В. та Ус Я. О. Перспективи розвитку малого бізнесу в Україні в умовах Четвертої промислової революції 3 урахуванням досвіду $\in$. Механізм регулювання економіки. 2016. № 4. С. $138-144$

6. Державна служба статистики України.URL:

http://www.ukrstat.gov.ua.

7. Попський А. Державна політика розвитку, підтримки малого та середнього підприємництва у контексті європейської інтеграції. Ефективність державного управління. 2017. ВИП. 1 (50). Ч. 2. C. 260-268.

\section{REFERENCES}

1. Kononova6 I. V. (2016). Conceptual bases of formation of drivers of development of social and economic system, Intelligence $X X I$, 6, 115-123.

2. Ministry of Development of Economy (2020). Trade and Agriculture of Ukraine. Retrieved from: https://www.me.gov.ua.

3. Kraus, N. M. (2019). Innovative economy in a globalized world: the institutional basis for the formation and trajectory of development. Kyiv: Agrar Media Group, Ukraine.

4. Pisarenko, T. V., Kvasha, T. K., Karlyuk, G. V. and Lyakh G. V. (2015). Innovative activity and its influence on economic development in Ukraine: monograph. Kyiv UkrNTI, Ukraine.
8. Іртищева І. О., Стройко Т. В., Гросицька О. Є., Стегней М. І. Вплив глобалізації на рівень конкурентоспроможності національної економіки: фактори, механізми, інструменти. Вісник Харківського національного аграрного університету ім. В. В. Докучаєва. Сер.: Економічні науки. 2013. № 4. С. 34-45

9. Irtyshcheva I., Kramarenko I., Shults S., Boiko Y., Blishchuk K., Hryshyna N., Popadynets N., Dubynska I., Ishchenko O. and Krapyvina D. Building favorable investment climate for economic development. Accounting. 2020. Volume 6. Number 5. Pp.773-780.

5. Chortok, Yu. V., Pimonenko, T.V. and Us, Ya. O. (2016). Prospects of small business development in Ukraine in the conditions of the Fourth Industrial Revolution taking into account the experience of the $\mathrm{EU}$, The mechanism of economic regulation, 4, 138-144.

6. State Statistics Service of Ukraine (2020). Retrieved from: http://www.ukrstat.gov.ua/

7. Popsky, A. (2017). State policy of development, support of small and medium enterprises in the context of European integration. Efficiency of public administration, 1 (50) 2, 260-268.

8. Irtyshcheva, I. O., Stroyko, T. V., Grositskaya, O. E. and Stegney, M. I. (2013). The impact of globalization on the level of competitiveness of the national economy: factors, mechanisms, tools, Bulletin of Kharkiv National Agrarian University. BB Dokuchaev. Ser.: Economic Sciences, 4, 34-45.
10. Іртищева І. О., Крамаренко І. С. Інвестиційна привабливість економіки: міжрегіональні асиметрії. Регіональна економіка 2014. № 2 (72). С. 84-95.

11. Крамаренко І. С., Войт Д. С., Кравець Л. О. Ефективність використання інвестиційного потенціалу національної економіки у контексті впливу на економічне зростання. Вісник ХНАУ. 2019. № 1. С. 403-413.

9. Irtyshcheva, I., Kramarenko, I. Shults, S., Boiko, Y., Blishchuk, K., Hryshyna, N., Popadynets, N., Dubynska, I., Ishchenko, O. and Krapyvina, D. (2020). Building favorable investment climate for economic development, Accounting, 6(5), 773-780.

10. Irtyshcheva, I. O. and Kramarenko, I. S. (2014). Investment attractiveness of the economy: interregional asymmetries", Regional economy, 2 (72), 84-95.

11. Kramarenko, I. S., Voit, D. S. and Kravets, L. O. (2019). Efficiency of using the investment potential of the national economy in the context of the impact on economic growth. Bulletin of KhNAU, 1, 403-413. 